\title{
Campbell Collaboration og arbeidet for å fremme kunnskapsbasert sosialpolitikk
}

\author{
Eamonn Noonan \\ Campbell Collaboration og Nasjonalt kunnskapssenter for helsetjenesten \\ E-post: eno@nokc.no Telefon: 46400401
}

\begin{abstract}
SAMMENDRAG
Artikkelen presenterer The Campbell Collaboration og skisserer organisasjonens aktiviteter siden 2008, da organisasjonens sekretariat ble flyttet til Nasjonalt kunnskapssenter for helsetjenesten i Oslo. Hovedfokuset for The Campbell Collaboration er produksjon av systematiske oversikter som del av en bredere innsats for å fremme kunnskapsbasert sosialpolitikk. Artikkelen omtaler trender i nyere oversikter og eksempler på tema og inklusjonskriterier for primærstudier. Artikkelen konkluderer med at en utvikling i retning av kunnskapsbasert praksis både er viktig og mulig, men at dette er avhengig av at det skapes større plass i Norge og internasjonalt for kvantitativ forskning, for systematiske forskningssynteser, og for møteplasser mellom praksis og forskning.
\end{abstract}

Noonan E. The Campbell Collaboration - contributing to evidence informed social policies. Nor J Epidemiol 2013; 23 (2): 177-180.

\section{ENGLISH SUMMARY}

This article presents the Campbell Collaboration and outlines the body's activities since 2008, when its secretariat was relocated to the Norwegian Knowledge Centre for the Health Services in Oslo. The main focus of the the Campbell Collaboration is the production of systematic reviews, as part of a broader engagement for the promotion of evidence-based social policy. The article considers trends in recent reviews on matters such as choice of subject and inclusion criteria for primary studies. The concluding section suggests that the development of evidence-based practice is both important and possible. However, progress depends on creating more space both in Norway and internationally for quantitative research, for systematic research synthesis, and for enhanced dialogue between researchers and practitioners.

This is an open access article distributed under the Creative Commons Attribution Licence, which permits unrestricted use, distribution, and reproduction in any medium, provided the original work is properly cited.

At det er en nær sammenheng mellom helsetilstand og sosiale forhold er velkjent, ikke minst blant epidemiologer. Kunnskap om samspillet mellom helse og sosiale faktorer har blant annet stor betydning ved utforming og iverksetting av helsepolitiske tiltak, for eksempel for å bidra til å utjevne sosiale ulikheter i helse.

Det teoretiske fundamentet for evidensbasert medisin (EBM) ble utviklet i løpet av 1980- og 90-tallet, og bidro til en tilsvarende tenkning innen sosialpolitikk og praksis. Størrelser som Eileen Gambrill (1) og Leonard Gibbs (2) bygget på EBM-konsepter utviklet av David Sackett og andre (3) når de formulerte sitt syn på kunnskapsbasert praksis på sosialfeltet.

\section{CAMPBell-OVERSIKTER}

The Campbell Collaboration er et frivillig nettverk av forskere, praktikere, ledere og forbrukere, som alle har samme mål: å bygge et omfattende bibliotek av relevante og dagsaktuelle systematiske oversikter om effekt av tiltak innen samfunnsvitenskapene (4). Systematiske oversikter kan gi et bedre kunnskapsgrunnlag for politiske beslutninger og kan bidra til kunnskapsbasert praksis på mange områder (5). Campbell-samarbeidet dekker i dag fire store fagfelt: Velferd, kriminalitet og rettsvesen, utdanning og internasjonal utvikling.

Innen Campbell Collaboration praktiseres strenge metodiske standarder for utvikling av systematiske oversikter ("Campbell-oversikter"); framgangsmåten omtales som den mest brukte og anerkjente for utarbeiding av systematiske oversikter innen samfunnsfagene (6). Campbell-oversikter er gjenstand for omfattende fagfellevurdering $i$ en prosess som er bygget på modellen utviklet av The Cochrane Collaboration. Dette innebærer utarbeidelse og godkjenning av en prosjektplan, et systematisk litteraturs $ø k$, vurdering av studier, datauthenting fra de inkluderte studiene, og syntese av data $\mathrm{i}$ en metaanalyse når dette er hensiktsmessig. For å sikre oversiktens kvalitet er det krav om at minst to forskere tar seg av sentrale oppgaver parallelt og uavhengig av hverandre. Den ferdige oversikten er å regne som en "levende" ressurs - den skal oppdateres jevnlig. Utvikling av Campbell-oversikter krever både høy kompetanse i prosjektgruppen, samt en grundig og støttende redaksjonell prosess. For en nærmere omtale av systematiske oversikter, se Jamtvedts artikkel i dette nummeret av Norsk Epidemiologi (7). 


\section{SOLID GRUNNLAG FOR BESLUTNINGER}

The Campbell Collaboration er fundert på troen på at grundig evaluering er et verktøy som kan brukes til å forbedre praksis, og at en systematisk gjennomgang av gjennomførte evalueringer kan bidra til å forutsi den forventede nytten av ulike tiltak. En systematisk oversikt er dermed en forutsetning for rasjonelle beslutninger, for eksempel når det skal velges blant ulike handlingsalternativer. Dersom en systematisk oversikt viser at et tiltak er ineffektivt, eller kanskje til og med skadelig, kan denne kunnskapen bidra til at en unngår dårlige beslutninger og dårlig ressursbruk. Gjennom å opparbeide en stadig større samling av systematiske oversikter over et bredt spekter av emner vil det også bli enklere for tjenesteytere å holde seg oppdatert på dagens kunnskap.

\section{DE SISTE ÅRS UTVIKLING INNEN CAMPBELL}

Antallet Campbell-oversikter har økt betydelig siden hovedkontoret flyttet til Oslo i 2008, og en gjennomgang av publiserte oversikter de siste årene viser noen viktige trender. Dette gjelder blant annet omfanget av hver enkelt oversikt, kriterier for inklusjon og eksklusjon av studier i oversiktene, den tematiske bredden, og strategier for formidling av resultater.

Campbell-oversikter omhandler enten spesifikke tiltaksprogrammer, eller flere forskjellige program med samme formål. Eksempler på det første er tiltak som "Scared Straight" (8) og Multisystemisk terapi (9). Eksempler på det andre er tiltak for forbedring av skolemat (10), og tiltak for å få flere tilbake i arbeid (11). I det siste har trenden gått i retning av bredere problemstillinger. Noen ferske eksempler er skolebaserte programmer mot mobbing (12), og tiltak mot frafall fra skole (13).

\section{Inklusjonskriterier}

For at en oversikt kan betraktes som systematisk er det et krav at man har klare, forhåndsdefinerte kriterier for hvilke studier som skal inkluderes. En utbedt feiloppfatning av både Campbell og Cochrane Collaboration har vært at det bare fokuseres på randomiserte evalueringer - eksperimentell forskning der loddtrekning brukes for å avgjøre hvem som skal motta det aktuelle tiltaket og hvem som skal inngå i kontrollgruppen. Dette stemmer selvfølgelig ikke. Campbell-samarbeidet står for en pragmatisk, men prinsippfast tilnærming til inklusjonskriterier. Vi leter etter pålitelig dokumentasjon om effekt av tiltak, og ikke-randomiserte studier kan også generere pålitelige resultater. Evalueringsstudier med bruk av kvasi-eksperimentelle metoder, for eksempel avbrutte tidsserieanalyser, tas gjerne inn i Campbell-oversikter. Uttrykket "kvasi-eksperimentell design" stammer for øvrig fra psykologen og forskeren Donald Campbell (1916-1996), som var en sentral inspirasjon for mange av dem som var med å starte Campbell-samarbeidet - derav navnevalget.

På noen områder innen sosialfeltet er bruk av randomiserte studier utbredt. Ett eksempel er Campbell- oversikten om Multisystemisk terapi (MST) for ungdom med sosiale, emosjonelle og atferdsvansker (8). Oversikten er basert på åtte randomiserte studier, og viser at MST verken var bedre eller verre enn alternative behandlinger (inkludert vanlig behandling /"treatment as usual").

Men på en rekke områder er randomiserte evalueringer fraværende. Dette gjelder for eksampel slektsplassering for barnevernsbarn. I en Campbell-oversikt om temaet valgte derfor forfatterne å inkludere ikkerandomiserte studier - så sant de oppfylte noen definerte kvalitetskrav (14). Oversikten omfatter 62 studier fra de siste 15 år, fra flere land, og viser bedre resultater med tanke på atferd, psykisk helse, og trivsel blant barn som er blitt plassert med slektninger sammenlignet med barn i vanlige fosterhjem.

Campbell-oversikten over tiltak mot frafall fra skole inkluderte 150 studier, hvorav $60 \%$ randomiserte fors $ø \mathrm{k}$ (14). Analysen viser at de fleste skole- og samfunnsbaserte programmer virker. Implikasjonen er at slike programmer, uavhengig av type, kan forventes å redusere frafallet fra skoler dersom implementeringen er god, og dersom programmet er tilpasset lokale forhold.

\section{Flere oversikter og flere tema}

Antall Campbell-oversikter vokser, og stadig flere emner blir forsket på (se figur 1). Etableringen i 2011 av en gruppe som fokuserer på utviklingspolitiske tiltak har bidratt til dette. Eksempler på Campbell-oversikter med særlig relevans for lav- og mellominntektsland er forebygging av kjønnslemlestelse (15) og tiltak for å få flere inn i skolen (16). Ett eksempel på en fersk systematisk oversikt fra Campbell Collaboration er tiltak for å redusere skulking blant skoleelever (17), der forfatterne fant at målrettede tiltak nyttet. Ingen av de evaluerte programtypene skilte seg ut som klart mer effektive enn andre. Det innebærer også at det ikke var støtte for en utbredt oppfatning blant fagfolk: At samarbeidsbaserte (collaborative) og sammensatte programmer er mer effektive enn enkle tiltak eller tiltak som ikke er samarbeidsbaserte. En annen oversikt som nylig ble publisert dreiet seg om politiets avhørsmetoder (18). Her fant forfatterne dokumentasjon for at en informasjonsinnhentende tilnærming, heller enn en anklagende tilnærming, øker sannsynligheten for "sanne" tilståelser og reduserer sannsynligheten for "falske". Rusbehandlingsprogrammer i fengsel er også blitt satt under lupen i det siste (19). Sett under ett har disse programmene - i den grad de er blitt evaluert en signifikant, moderat effekt på tilbakefall til kriminalitet, men liten eller ingen effekt på tilbakefall til rusavhengighet.

\section{Formidling av resultater fra systematiske oversikter}

Akkurat som i helsesektoren er det utfordringer knyttet til formidling av funn fra systematiske oversikter blant annet fordi dette er en sjanger som sjelden er lettlest. For å gjøre funnene forståelige for aktuelle målgrupper bør hver systematisk oversikt ha et sammendrag i klar og enkel språkdrakt (en "plain language summary"). Dessuten vil det ofte være hensiktsmessig 


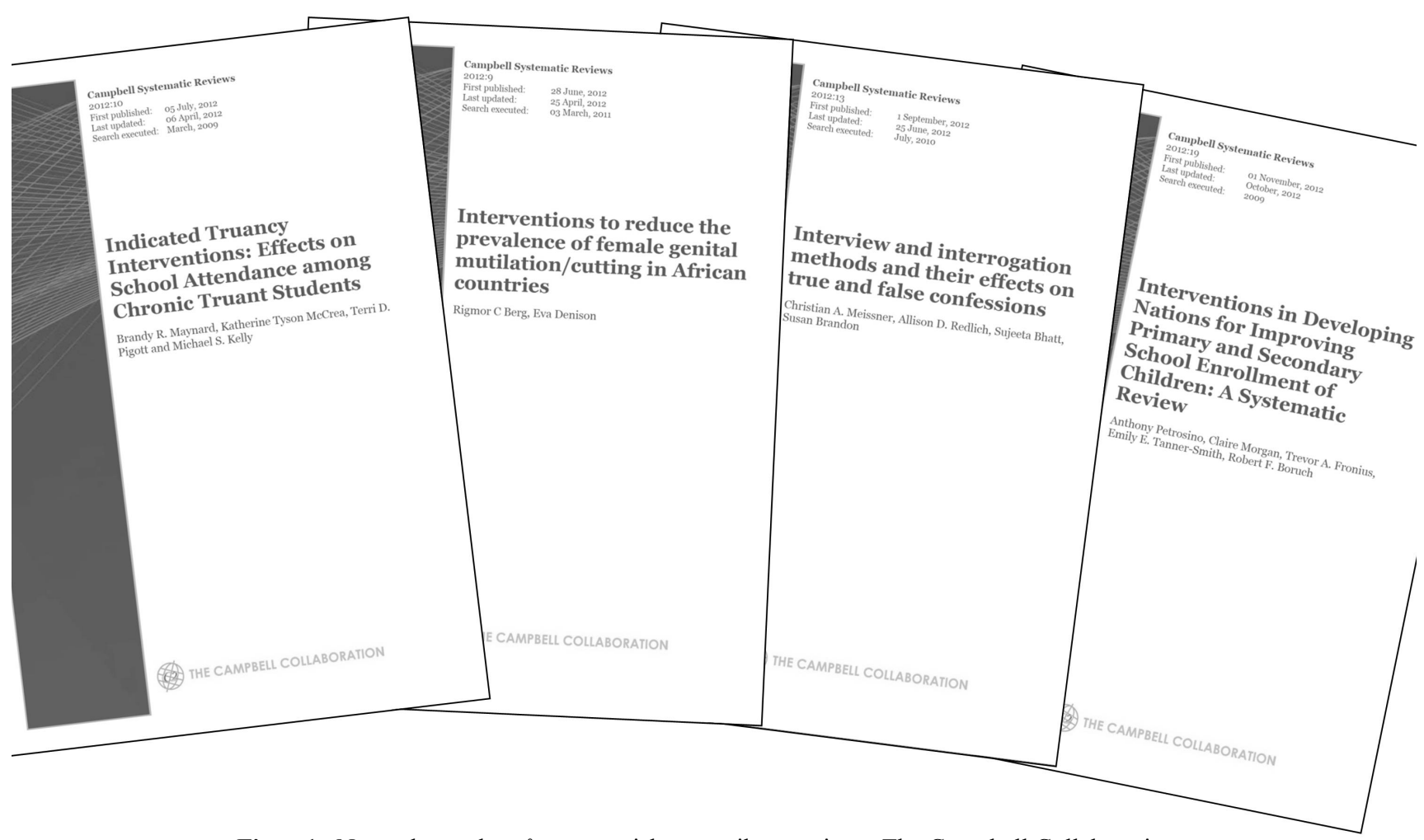

Figur 1. Noen eksempler på systematiske oversikter utgitt av The Campbell Collaboration.

å utarbeide et kort frittstående sammendrag der funnene ses $\mathrm{i}$ sammenheng med den aktuelle samfunnsdebatten rundt temaet, i den aktuelle settingen - for eksempel i Norge. For å bidra til å gjøre forskningsfunn tilgjengelige satser Campbell på Open Accesspublisering. Alle protokoller, oversikter og kortreferater er tilgjengelige på Internett, gratis i fulltekst (www.campbellcollaboration.org). Campbell Collaboration Online Library ble lansert i 2010, og skriftserien Campbell Systematic Reviews har oppnådd en bred leserkrets. Over 700000 dokumenter har blitt lastet ned hittil, og tolv av oversiktene er blitt lastet ned over 10000 ganger hver.

\section{Avslutning}

Takket være iherdig innsats over flere år bl.a. gjennom Campbells søsterorganisasjon, Cochrane Collabora- tion, har helsepersonell tilgang til en rekke ressurser som gir oversikt over forskning på virkninger av behandling og andre tiltak i helsesektoren. Det er et stykke igjen til sosialarbeidere, lærere eller politi får et tilsvarende tilbud med tanke på tilgang til kvalitetssikret informasjon om resultater fra effektforskning. Campbell-samarbeidet har som mål å bidra til å realisere dette. Ved å utnytte bedre hva forskningen kan si oss, kan vi forbedre tjenestene som leveres til publikum, og dermed forbedre folks liv. Dette er ingen enkel oppgave, men er vel verdt å satse på! Mer bruk av forskningsbasert kunnskap i politikk og praksis er ikke en utopisk framtidsvisjon, men kan oppnås dersom det legges større vekt på gode og grundige effektevalueringer, systematiske oppsummeringer av slik forskning, og bedre kommunikasjon mellom praktikere og forskere.

\section{REFERANSER}

1. Gambrill E. Evidence-based practice: An alternative to authority-based practice. Families in Society 1999; 80: 341-350.

2. Gibbs LE. Evidence-based practice for the helping professions: A practical guide with integrated multimedia. Pacific Grove, Calif: Brooks/Cole-Thomson Learning, 2003.

3. Sackett DL, Richardson WS, Rosenberg W, Haynes RB. Evidence-based medicine: How to practice and teach EBM. New York: Churchill Livingstone, 1997.

4. Shlonsky A, Noonan E, Littell J, Montgomery P. The role of systematic reviews and the Campbell Collaboration in the realization of evidence-informed practice. Clinical Social Work Journal 2011; 39 (4): 362-368.

5. Petticrew M, Roberts H. Systematic reviews in the social sciences: a practical guide. Oxford: Blackwell, 2006.

6. Cooper H, Hedges LV, Valentine JC (eds). The handbook of research synthesis and meta-analysis. New York: Russell Sage, 2009: 431-440. 
7. Jamtvedt G. Systematiske oversikter om effekt av tiltak. Norsk Epidemiologi 2013; 23 (3): 119-124.

8. Petrosino A, Turpin-Petrosino C, Buehler J. "Scared Straight" and other juvenile awareness programs for preventing juvenile delinquency. Campbell Systematic Reviews 2004; 0 (2).

9. Littell J, Popa M, Forsythe B. Multisystemic therapy for social, emotional, and behavioral problems in youth aged 10-17. Campbell Systematic Reviews 2005; 1 (1).

10. Kristjansson EA, Robinson V, Petticrew M, MacDonald B, Krasevec J, Janzen L, Greenhalgh T, Wells G, MacGowan J, Farmer A, Shea BJ, Mayhew A, Tugwell P. School feeding for improving the physical and psychosocial health of disadvantaged students. Campbell Systematic Reviews 2006; 2 (14).

11. Smedslund G, Hagen KB, Steiro A, Johme T, Dalsbø TK, Rud MG. Work programmes for welfare recipients. Campbell Systematic Reviews 2006; 2 (9).

12. Farrington DP, Ttofi MM. School-based programs to reduce bullying and victimization. Campbell Systematic Reviews 2009; 5 (6).

13. Wilson SJ, Tanner-Smith EE, Lipsey, MW, Steinka-Fry, K, Morrison, J. Dropout prevention and intervention programs: Effects on school completion and dropout among school aged children and youth. Campbell Systematic Reviews 2011; 7 (8).

14. Winokur M, Holtan A, Valentine D. Kinship care for the safety, permanency, and well-being of children removed from the home for maltreatment. Campbell Systematic Reviews 2009; 5 (1).

15. Berg RC, Denison E. Interventions to reduce the prevalence of female genital mutilation/cutting in African countries. Campbell Systematic Reviews 2012; 6 (9).

16. Petrosino A, Morgan C, Fronius TA, Tanner-Smith EE, Boruch RF. Interventions in developing nations for improving primary and secondary school enrollment of children. Campbell Systematic Reviews 2012; 6 (19).

17. Maynard BR, McCrea KT, Pigott TD, Kelly MS. Indicated truancy interventions: Effects on school attendance among chronic truant students. Campbell Systematic Reviews 2012; 6 (10).

18. Mitchell O, Wilson D, MacKenzie DL. The Effectiveness of incarceration-based drug treatment on criminal behavior. Campbell Systematic Reviews 2012; 6 (18).

19. Meissner CA, Redlich A, Bhatt S, Brandon S. Interview and interrogation methods and their effects on true and false confessions. Campbell Systematic Reviews 2012; 6 (13). 